\title{
Practice of Flipped Classroom in College English Listening and Speaking Based on WeChat
}

\author{
Juxiang Wen \\ College English Teaching Department \\ Zaozhuang University \\ Zaozhuang, China
}

\begin{abstract}
WeChat is becoming increasingly popular and the first choice of Chinese people's public platforms. Meanwhile, it's becoming the new learning platform for modern Chinese college students. The reform of College English teaching has been focusing on learner-centered philosophy and improving the student's comprehensive application ability all the way and constantly emphasizes to enhance the students' listening and speaking skills, which is the important and difficult point of College English teaching. Flipped Classroom based on the WeChat Public Platform, the new teaching mode, solves these problems of College English listening and speaking with its unique advantages. This paper analyzes present College English teaching situation and its reasons in Zaozhuang University, illustrates the term of flipped classroom based on the WeChat Public Platform, compares the flipped classroom with the normal preview teaching method, discusses the difficulties and benefits of flipped classroom based on the WeChat Public Platform, and hopes to provide some useful suggestions for solving the problems of College English listening and speaking.
\end{abstract}

Keywords-WeChat public platform; flipped classroom; teaching mode; college English listening and speaking

\section{INTRODUCTION}

Nowadays, we are in the information age with the rapid development of network technology. Researches on Moocs, Micro-teaching, and other forms of online curriculum construction have become a hot spot at home and abroad in recent years. These new teaching models are drawing more and more attention of higher education reformers. College English teaching, as a compulsory course of higher education for general education, needs to focus on the use of these innovative teaching modes. This research reports The Practice and Inspiration of Flipped Classroom in College English Listening and Speaking Based on the WeChat Public Platform. The study took College English Listening and Speaking in Zaozhuang University for example, and aimed at finding out possible ways to solve the problems of China's College English teaching and providing others with some useful suggestions of the combination of language teaching and network information technology.

In the past few years, College Entrance Examination in China, especially for English course, experienced some reforms: in Shandong province, the basic ability test of English and listening part of English test were cancelled in
2014; English test officially exited from the college entrance examination in 2016. [1] Many people believe that these decisions can lighten the learning burden of students and cool down the English learning heat in recent years. But the elimination of the hearing test will have a very seriously negative effect on English teaching in high schools, middle schools and even primary schools and universities. We have to think about the current situation and reform of college English teaching, especially listening and speaking teaching.

Listening, speaking, reading, writing and translating are the main ways to acquire information and language feelings. The famous foreign language teaching Professor Wilga M.Rivers in America did a research on listening, speaking, reading and writing of grown-up native English speakers. According to the result of it, listening accounts for $45 \%$ of the actual time of people's communication activities, saying $30 \%$. To sum up, listening and speaking activities in human communication play a very important role. However, for many college students, listening and speaking ability is just like a bottleneck of effective communication in English There are many reasons, such as objective factors including listening materials and the content, the teaching environment and methods, and subjective factors including the base of college students' English knowledge and skills, and choice and use of learning methods and strategies, etc. In addition, the actual teaching situation of college English is one of the main factors that lead to the students' weak listening and speaking ability. During the four semesters' College English teaching, there are totally about 192 periods (4 periods each week in grade 1,2 periods in grade 2 ). There's only 1 period of listening and speaking teaching each week averagely. Therefore, there are less than 70 periods in total for listening and speaking. Many universities are planning to reduce college English credits or take College English as an elective course. [2]

The ten-year's development plan of Educational Information (2011-2020) in China, pointed out that we'll establish the new information-based teaching environment, innovate information teaching and learning, enhance the level of personalized interactive teaching and innovation, create new modes to cultivate talents and improve the quality of talent cultivation on the basis of deep combination of education and information technology. [3] "Flipped classroom" can make College English Listening and 
Speaking classes more attractive to a large degree by adopting interacting ways such as the videos before the class, cloud platform and WeChat public platform.

\section{WECHAT PUBLIC PLATFORM AND "FLIPPED ClassRoOM"}

\section{A. The Introduction of WeChat}

WeChat is interactive software developed by the famous Internet Company of Tencent. It can deal with texts, pictures, voice and videos. WeChat can provide moments, public platforms, and message sending. Through the WeChat public platform, users can share lots of wonderful things with their friends. Relevant data show that college students accounted for a large part of WeChat. It has already changed the students' life style and learning style, which has caused profound effect on them.

\section{B. The Flipped Classroom Teaching Mode}

In the traditional classes, the teacher imparts the knowledge in class; the students do homework and consolidate what they have learned after class. "Flipped Classroom" will reverse the order that the teacher gives the class first and then the students absorb knowledge. It changes the roles between teachers and students in the traditional Classroom, and rearranges class time. In 2007, two chemistry teachers, Jon Bergmann and Aaron Sams in Woodland Park High school in Colorado Rocky Mountain in the United States, made a PPT, and put it online to help students to make up for their missing classes. Students were asked to watch teaching videos before class, finish their assignment and explain the problems they encountered in class. The two teachers later found that this teaching mode was popular among students. [4] On January 30, 2012, they hosted the "Open Days of flipped Classes" in Woodland Park High School, which makes more teachers to watch the videos, know the students 'learning situation and understand the idea and method of the flipped classrooms. This practice makes the teaching mode of "flipped classroom" be widely promoted. In addition, the open education resources (OER) campaign has further promoted the teaching mode of flipped classroom. Following the movement of open courseware $(\mathrm{OCW})$ at the Massachusetts institute of technology (MIT), Yale University's open courses, micro videos at Khan Academy, TED education channel and other kinds of videos provide the mode of flipped classroom with the high quality teaching resources and promote its development as well. [5]

\section{ThE PRACTICE IN COLLEGE ENGLISH LISTENING AND SPEAKING}

\section{A. The Construction of Flipped Classroom Teaching Mode Based on the WeChat Public Platform}

First, the WeChat public platform needs to set up. The construction of flipped classroom teaching mode is supported by the WeChat public platform. Therefore, the first thing that the English teachers have to do is to set up a WeChat public account for the class in the teaching process. The teacher can put assignments online, play the videos and show students his teaching materials by the WeChat public account. Students can forward the materials to others, ask questions, communicate with other students and the teacher and then let more people benefit from them. The teacher also can learn the situation of students through background data. The WeChat public account can not only make the teacher and students contact each other in time but also improve the students' learning efficiency.

Second, assignments need to be designed well before the class. Before the class starts, the teacher needs to upload the assignments to WeChat public platform. Students learn and understand each class task before class, and then finish the task before class as well. The assignments are very relevant to the teaching contents in class. Generally speaking, the tasks before class include making videos, doing oral assignments, learning the background information of the class, or collecting data and organizing materials, which need to be done with the aid of network. The students finish the tasks assigned by the teacher after video watching or text viewing by themselves.

Third, in-class assignments need to be designed. In-class assignments should focus on the communication between the teacher and students. In class, the teachers should give proper guidance and make the objective evaluation. During the teaching, the teacher can divide the class into several groups. It's better to make each group less than 5 students. Each group fully discusses the before-class assignments and chooses a representative to make a presentation about their discussing result. During students' presentations, the teacher can record the students' statements by using a recording pen or other recording tools, make appropriate comments, correct the students 'pronunciation and so on.

\section{B. The Design and Methods of the Experiment}

- The study was designed as a quasi-experiment, taking two natural classes of freshmen students in our university as the subjects, experimental class and control class last year. During the two semester's follow-up study, I gave students in the experimental class by the "flip" classroom teaching mode, and students in the control class according to the traditional teaching mode (the students' before-class self-preparation, the teacher's in-class teaching, and after-class knowledge consolidation by doing homework). According to the basic and learning style of the students, I also divided "flipped classroom" teaching into three stages: before-class in-class and after-class. The flipped classroom teaching mode mainly refers to the flipping between before-class and in-class parts.

- The activities before class: I design the learning task list first, in order to help students to clarify the content of preview, learning goals, etc. I usually make a teaching video for 5-10 minutes. If the content is a bit more, I will extend it to 15 minutes or so. A year's teaching practice proved that college students can focus on the teaching videos much longer than primary pupils and middle school students. During 
this period, I will explain the important and difficult words, sentence patterns, grammar, related cultural background, or even original text of the listening content. In the process of teaching video making, I pay much attention to visual effect. So, I often search for other teaching resources, and find out the video resources associated with this class teaching content, such as text, pictures, video and other interesting resources to show the use of knowledge. That's because language learning environment is important for College English different from other disciplines. If Students encounter difficulties and problems during before-class learning, they can ask me or other students through WeChat, telephone or other communication tools. Therefore, the students can know other's harvest and doubts, and it also make the important and difficult points clear to me.

- The activities in class: I guide students to actively explore the answer to these questions that I summarized according to their teaching contents and the questions raised by students during their beforeclass learning. In the design of flipped classroom activities, I also pay attention to cultivate the students' self-learning ability. The main goal of listening and speaking course is to improve students' listening and speaking skills. The constructionists think that the process of acquiring knowledge is the process of meaning construction the students did by interactive activities in a certain environment. [6] Therefore, in class, I will use the saved time through before-class video watching to students' cooperative learning activities such as dialogue making, discussion and so on. It will improve the students' critical thinking ability, communication ability, and the students' innovative thinking ability.

- The activities after class: there are always a few questions unsolved in class, or some new questions appearing the students have encountered in their after-class learning. They can continue to interact with classmates and teachers through WeChat public platform. At the same time, they can also write down their feelings, learning experience and a summary in the personal space, and thus that can not only promote students' knowledge internalization but also provide the teacher' evaluation about their learning process and efforts with a valuable reference.

\section{Analysis of the Experiment Results}

After two semesters' practice teaching, students 'listening and speaking abilities in both the experimental class and the control class have improved. However, improvement of the students in the experimental class is more obvious. When they entered the university, the average score of one class is only 0.09 point higher than that of another class. The students' average score of listening part of the final exam in the experimental class is separately 1.32 and 2.57higher than that of the control class. The score distribution of experimental class is more normal than that of the control class. And the students in the experimental express stronger desire to talk and speak more fluent as well.

Unusually, there are about 70 students in one College English class. It's hard for the teacher focus on every student. The teacher can only pay attention to the major part of students (those are in the middle). Therefore, both the students who learned faster and better and those who learned slower and worse are easily neglected. The teaching mode of flipped classroom can solve the problem, pay attention to students at any level, highlight the students' status, and make students with a good foundation learn much better and students with a not so good foundation absorb the knowledge as well, because this teaching mode help the teacher send the teaching contents in the traditional class to students before the class starts so they can watch the teaching videos or other kinds of materials before class, and they can watch and pause the video over and over again if they need to. They also can ask for other's help or look up the new words in the dictionary and then continue the video. Flipped classroom changes the in-class teaching to pre-class video watching, changes students' after-class practice to in-class discussion or exercise. Last but not least, this mode changes the teacher's "monologue" to "chorus" between teachers and students, and enhances the interaction between teachers and students.

The teacher's burden is aggravated because the flipped classroom based on $\mathrm{WeChat}$ has higher requirement for the teacher's information ability. [7] It takes a lot of time and efforts to make a beautiful, high-quality teaching video. Teachers of foreign language majors unusually are not good at the computer, and thus it is necessary for them to actively acquire the knowledge of micro-course.

\section{Questionnaire and Feedback Analysis}

- Through the collection and analysis of the feedback information of the questionnaire about flipped classroom teaching mode based on WeChat, I found that the overwhelming majority of students like the teaching mode. They are neither distracted when they can' $\mathrm{t}$ understand the teacher's instruction nor choose to be silent listeners. Students said that they were more confident and interested in listening and speaking in English because they made a good preparation for the in-class discussion or conversations before the class began through the video watching. From the results of the two final examinations, the students in the experimental class have significantly improved their performance compared with those of the control class. Most students, especially those with weak foundation, believe that they have greatly enhanced their attention to College English listening and speaking course.

- During the survey, the students of the teaching mode mainly put forward the following suggestions: it's not good for the teacher to send learning resources to students too early or too late. It had better be about a week before the class because it's convenient for students to arrange their time and their passion and 
enthusiasm for the topic will not dim. They want more opportunities to display themselves and do group activities, and hope the teacher give comments and encouragement in time. Although the teaching mode of flipped classroom based on WeChat is easy to operate and not limited by learning place and time, it still has certain shortcomings and limitations. For example, the students sometimes are easily attracted by their friends' messages irrelevant to learning, and the teacher can't get the detailed information about the students' learning time, content and quality.

\section{CONCLUSION}

Although the teaching model of flipped classroom based on WeChat public platform is not very mature, it has great significance for college English teaching. In a word, college English teachers need to properly combine WeChat public platform with the teaching model of flipped classroom in order to improve the students' academic achievement and the quality of college English teaching.

We also need to remember that pre-class videos, online videos and online classes are not equal to flipped classroom, and the short videos for flipped classroom are not simple online videos and which are not to let students learn in isolation and disorder. Flipped classroom teaching mode based on WeChat public platform provides students with timely and effective guidance, solves the problem of insufficient class time for college English, and improve the students' autonomous learning ability. There are challenges from many aspects for teachers too, such as their teaching philosophy, their knowledge, ability structure and so on. The teachers need to face these challenges, bear the studentcentered teaching philosophy in mind, build their ability structure, improve their knowledge, and make the most of the teaching mode of Flipped Classroom in College English Listening and Speaking Based on the WeChat Public Platform.

\section{REFERENCES}

[1] "College Entrance Examination English reform in 2014: summary of the reform measures in all provinces," Sohu Education 26 August 2014.

[2] Wang Shouren and Yao Chenghe, "Some thoughts on academic English teaching," Foreign Languages in China, 2013(5).

[3] "The ten-year's development plan of educational information (20112020) in China," Ministry of Education, P.R.C.

[4] Jin Ling, "2017, On the retrospect and prospect of the flipped class," China Information Technology Education, 2017(1).

[5] Xu Haiyan, "An explorative study of college students' critical thinking under flipped classroom," Technology Enhanced Foreign Language Education, 2017(2).

[6] He Kekang, "Contructivism, the theoretical basis of traditional teaching innovation," e-Education Research, 1997(3).

[7] Wu Renying and Wang Tan, "Flipped classroom: practical challenges faced by teachers and corresponding strategies," Educational Research, 2017(2). 